ECLETICA

www.scielo.br/eq

www.ecletica.iq.unesp.br

Volume 33, número 3, 2008

\title{
Biheterocyclic ligands: synthesis, characterization and coordinating properties of bis(4-amino-5-mercapto-1,2,4- triazol-3-yl) alkanes with transition metal ions and their thermokinetic and biological studies
}

\author{
H. M. Al-Maydama*, T. E. Y. Al-Ansi, Y. M. Jamil and A. H. Ali \\ Chemistry Deparment, Faculty of science, Sana'a University \\ P.O. Box 12286 Sana'a Republic of Yemen \\ *hmaydama@yahoo.com
}

\begin{abstract}
The $\mathrm{Co}(\mathrm{II}), \mathrm{Ni}(\mathrm{II})$ and $\mathrm{Cu}(\mathrm{II})$ metal ions complexes of Bis(4-amino-5-mercapto-1,2,4-triazol-3-yl) alkanes (BATs) have been prepared and characterized by elemental analysis, conductivity measurements infrared, magnetic susceptibility, the electronic spectral data and thermal studies. Based on spectral and magnetic results, the ligands are tetradentate coordinating through the $\mathrm{N}$ and S-atoms of BATs; six-coordinated octahedral or distorted octahedral and some times four-coordinated square planar were proposed for these complexes. Activation energies computed for the thermal decomposition steps were compared. The ligands and their metal complexes were tested in vitro for their biological effects. Their activities against two gram-positive, two gram-negative bacteria and two fungal species were found to vary from moderate to very strong.
\end{abstract}

Keywords: Biheterocyclic Ligands; $\mathrm{Co}(\mathrm{II}), \mathrm{Ni}(\mathrm{II})$ and $\mathrm{Cu}(\mathrm{II})$ complexes; Synthesis; Characterization; Thermal Degradation; Kinetic Parameters; Biological Activities.

\section{Introduction}

In recent years, considerable attention has been paid to the synthesis of biheterocyclic compounds that play a significant role in many pharmacological, biological activities, therapeutic effect and plant growth [1-7]. Antimicrobial activities of some new biheterocyclic compounds were reported recently [5]. Antibacterial activities of biheterocyclic compounds are much better than that of heterocyclic [8]. Biheterocyclic compounds act as a powerful chelating agent, forming stable coordination polymers, complexes with various transition metals, trace elements, lan-
thanide(III), uranium(VI) and thorium(VI) ions [9-12] Based on spectral and thermal studies, a coordination number of seven was proposed for niobium(V) complexes with biheterocyclic ligand [13]. Six-coordination octahedral structures for some transition metal ions complexes of biheterocyclic ligands were determined by magnetic susceptibility measurements, and infrared and electronic spectral data [14].

In 1999, the synthesis of the biheterocyclic compounds of interest, Bis(4-amino-5mercapto-1,2,4-triazol-3-yl) alkanes, (BATs) were first reported [7] by P. F. Xu et al . The characteristic structure of the BATs (i.e. BAT1, BAT2, 
BAT3 and BAT4) is apparent in the existence of the sulfur of thione and nitrogen of amino groups on both sides of a molecule. This makes the compounds (BATs) electron-rich ligands. However, literature survey has revealed that no attempt has been made to study the complexes of some transition metal ions with the above mentioned ligand compounds. It is a thought of interest to study the synthesis and characterization of the $\mathrm{Co}(\mathrm{II})$, $\mathrm{Ni}(\mathrm{II})$ and $\mathrm{Cu}(\mathrm{II})$ complexes of BATs ligands. The processes of thermal degradation of these metal complexes have been investigated by thermoanalytical (TG, DTG) and Coats-Redfern integral method [15] has been used to determine the associated kinetic parameters for the successive steps in the decomposition sequence.

Some literatures [16-18] indicated that in some transition metal complexes with heterocyclic or biheterocyclic are biologically more active than the free ligands. Therefore, the biological activities of the ligands BATs and their metal complexes of the $\mathrm{Co}(\mathrm{II}), \mathrm{Ni}$ (II) and $\mathrm{Cu}(\mathrm{II})$ are tested against four strains of bacteria (i.e. two gram-positive and two gram-negative bacteria) and against two fungal species. The effect of the methylene group number between two heterocyclic rings on the biological activity [19] is considered.

\section{Experimental}

\section{Materials}

All chemicals, solvents, indicators, metal(II) chlorides, and starting materials required and used as appropriate, were commercially available from BDH and Aldrich chemical Co.

\section{Synthesis of the ligands}

The ligands 1,1 bis(4-amino-5-mercapto1,2,4-triazol-3-yl)methane (BAT1), 1,2 bis(4amino-5-mercapto-1,2,4-triazol-3-yl)ethane (BAT2), 1,3 bis(4-amino-5-mercapto-1,2,4-triazol-3-yl)propane (BAT3) and 1,4 bis(4-amino-5mercapto-1,2,4-triazol-3-yl)butane (BAT4) were prepared and purified according to the procedures reported in the literature [7]. All the prepared ligands collected after recrystallization show single spots on their thin layer chromatography with satisfactory $R_{f}$ values. These ligands are stable in atmospheric conditions, insoluble in water, completely soluble in dimethylformamide (DMF) and dimethylsulphoxide (DMSO) and partially soluble in ethanol, acetone and carbon tetrachloride. The elemental data and physical properties of these ligands are given in Table (1). The chemical structures of the ligands of interest under investigation are:

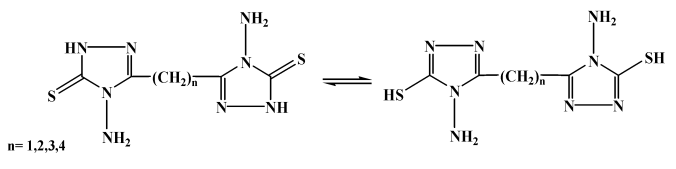

When

$\mathrm{n}=1$ : 1,1 bis(4-amino-5-mercapto-1,2,4-triazol3-yl)methane (BAT1)

$\mathrm{n}=2$ : 1,2 bis(4-amino-5-mercapto-1,2,4-triazol3-yl)ethane (BAT2)

$\mathrm{n}=3$ : 1,3 bis(4-amino-5-mercapto-1,2,4-triazol3-yl)propane (BAT3)

$\mathrm{n}=4:$ 1,4 bis(4-amino-5-mercapto-1,2,4-triazol3-yl)butane (BAT4)

\section{Preparation of the complexes}

For metal ion of $\mathrm{Co}(\mathrm{II}), \mathrm{Ni}(\mathrm{II})$ and $\mathrm{Cu}(\mathrm{II})$, complexes with the various ligands of interest (BAT1, BAT2, BAT3 and BAT4) were synthesized and collected pure after recrystallization.

In general, $0.01 \mathrm{~mol}$ of each ligand $(\mathrm{BAT} 1=2.44 \mathrm{~g}, \mathrm{BAT} 2=2.58 \mathrm{~g}, \mathrm{BAT} 3=2.72 \mathrm{~g}$ and BAT4=2.86 g) was dissolved warm in $100 \mathrm{ml}$ ethanol by warming up the solution. As 1: 2 mole ratio was adopted, a $0.02 \mathrm{~mol}$ metal chloride $\left(\mathrm{CoCl}_{2} \cdot 6 \mathrm{H}_{2} \mathrm{O}=4.758 \mathrm{~g}, \mathrm{NiCl}_{2} \cdot 6 \mathrm{H}_{2} \mathrm{O}=4.754 \mathrm{~g}\right.$ and $\mathrm{CuCl}_{2} \cdot 2 \mathrm{H}_{2} \mathrm{O}=3.4108 \mathrm{~g}$ ) in $50 \mathrm{ml}$ ethanol was added dropwise to the $0.01 \mathrm{~mol}$ ligand solution. The solution mixture was refluxed (3-4 hours) until precipitation occurred. The precipitates obtained were filtered off and recrystallized from ethanol and their yield percent are given in Table 1.

\section{Chemical and physical measurements}

Stuart scientific electrothermal melting point apparatus was used in measuring the melting point of the ligands and their complexes. Metal content was estimated using Perkin-Elmer 2380 atomic absorption spectrophotometer, and chloride was determined gravimetrically using standard method [20]. Carbon, hydrogen, nitro- 
Table 1. Analytical and Physical data of the BATs ligands and their $\mathrm{Co}(\mathrm{II}), \mathrm{Ni}(\mathrm{II})$ and $\mathrm{Cu}$ (II) complexes.

\begin{tabular}{|c|c|c|c|c|c|c|c|c|c|c|c|}
\hline \multirow{2}{*}{ Compound } & \multirow{2}{*}{ Color } & \multirow{2}{*}{$\begin{array}{c}\text { M.P } \\
{ }^{\circ} \mathrm{C}\end{array}$} & \multirow{2}{*}{$\begin{array}{c}\begin{array}{c}\text { Yield } \\
\%\end{array} \\
\%\end{array}$} & \multirow{2}{*}{$c \underset{\mathrm{mS} \mathrm{cm}^{2} \mathrm{~mol}^{-1}}{\Lambda_{\mathrm{m}}}$} & \multirow{2}{*}{$\mathrm{R}_{\mathrm{f}}$} & \multicolumn{6}{|c|}{ Elemental Analysis, Found (calculated)\% } \\
\hline & & & & & & $\mathrm{C}$ & $\mathrm{H}$ & $\mathrm{N}$ & $\mathrm{S}$ & $\mathrm{M}$ & $\mathrm{Cl}$ \\
\hline $\begin{array}{c}\text { BAT1 } \\
\mathrm{C}_{5} \mathrm{H}_{8} \mathrm{~N}_{8} \mathrm{~S}_{2}\end{array}$ & $\begin{array}{l}\text { Yellowish } \\
\text { white }\end{array}$ & 290 & 69 & 0.23 & 0.11 & \begin{tabular}{c|}
24.9 \\
$(24.6)$
\end{tabular} & $\begin{array}{c}3.5 \\
(3.3)\end{array}$ & $\begin{array}{c}45.8 \\
(45.9)\end{array}$ & $\begin{array}{c}26.7 \\
(26.2)\end{array}$ & - & - \\
\hline $\begin{array}{c}\text { BAT2 } \\
\mathrm{C}_{6} \mathrm{H}_{10} \mathrm{~N}_{8} \mathrm{~S}_{2} \\
\end{array}$ & White & 248 & 77 & 0.20 & 0.30 & \begin{tabular}{c|}
28.1 \\
$(27.9)$ \\
\end{tabular} & $\begin{array}{c}3.4 \\
(3.9) \\
\end{array}$ & $\begin{array}{c}43.7 \\
(43.4) \\
\end{array}$ & $\begin{array}{c}25.0 \\
(24.8) \\
\end{array}$ & - & - \\
\hline $\begin{array}{c}\text { BAT3 } \\
\mathrm{C}_{7} \mathrm{H}_{12} \mathrm{~N}_{8} \mathrm{~S}_{2}\end{array}$ & White & 227 & 95 & 0.15 & 0.38 & \begin{tabular}{c|}
31.2 \\
$(30.9)$ \\
\end{tabular} & $\begin{array}{c}4.1 \\
(4.4)\end{array}$ & $\begin{array}{c}41.3 \\
(41.2) \\
\end{array}$ & $\begin{array}{c}23.8 \\
(23.5)\end{array}$ & - & - \\
\hline $\begin{array}{c}\text { BAT4 } \\
\mathrm{C}_{8} \mathrm{H}_{14} \mathrm{~N}_{8} \mathrm{~S}_{2} \\
\end{array}$ & White & 239 & 80 & 0.13 & 0.15 & $\begin{array}{c}33.3 \\
(33.6) \\
\end{array}$ & $\begin{array}{c}5.1 \\
(4.9) \\
\end{array}$ & $\begin{array}{c}39.0 \\
(39.2) \\
\end{array}$ & $\begin{array}{c}22.1 \\
(22.4)\end{array}$ & - & - \\
\hline $\begin{array}{c}{\left[\mathrm{Co}_{2}(\mathrm{BAT} 1) \mathrm{Cl}_{4}\right]} \\
\cdot \mathrm{H}_{2} \mathrm{O} \cdot 1 / 3 \mathrm{C}_{2} \mathrm{H}_{5} \mathrm{OH}\end{array}$ & Dark brawn & $>350 \mathrm{dec}$ & 49 & 3.7 & 0.11 & $\begin{array}{c}12.7 \\
(12.7) \\
\end{array}$ & $\begin{array}{c}2.0 \\
(2.2)\end{array}$ & $\begin{array}{c}21.5 \\
(21.0) \\
\end{array}$ & $\begin{array}{c}12.0 \\
(11.9)\end{array}$ & $\begin{array}{c}21.5 \\
(21.9)\end{array}$ & $\begin{array}{l}26.0 \\
(26.4)\end{array}$ \\
\hline $\begin{array}{c}\left.\mathrm{Co}_{2}(\mathrm{BAT} 2) \mathrm{Cl}_{4}\right] \\
\cdot 3 / 4 \mathrm{H}_{2} \mathrm{O} \cdot 1 / 2 \mathrm{C}_{2} \mathrm{H}_{5} \mathrm{OH} \\
\end{array}$ & Dark gray & 257 & 55 & 4.1 & 0.32 & $\begin{array}{c}15.1 \\
(15.2) \\
\end{array}$ & $\begin{array}{c}2.9 \\
(2.6)\end{array}$ & $\begin{array}{c}20.7 \\
(20.2) \\
\end{array}$ & $\begin{array}{c}12.0 \\
(11.6)\end{array}$ & $\begin{array}{l}21.8 \\
(21.3)\end{array}$ & $\begin{array}{l}26.0 \\
(25.6)\end{array}$ \\
\hline $\begin{array}{c}{\left[\mathrm{Co}_{2}(\mathrm{BAT} 3)\left(\mathrm{H}_{2} \mathrm{O}\right)_{4} \mathrm{Cl}_{4}\right]} \\
\cdot 1 / 4 \mathrm{H}_{2} \mathrm{O} \cdot 1 / 3 \mathrm{C}_{2} \mathrm{H}_{5} \mathrm{OH}\end{array}$ & Gray & $>350 \mathrm{dec}$ & 63 & 4.8 & 0.34 & $\begin{array}{c}14.8 \\
(14.8)\end{array}$ & $\begin{array}{c}3.7 \\
(3.6)\end{array}$ & $\begin{array}{c}18.0 \\
(18.0)\end{array}$ & $\begin{array}{c}10.1 \\
(10.3)\end{array}$ & $\begin{array}{c}19.0 \\
(18.9)\end{array}$ & $\begin{array}{l}23.0 \\
(22.7)\end{array}$ \\
\hline $\begin{array}{c}{\left[\mathrm{Co}_{2}(\mathrm{BAT} 4)\left(\mathrm{H}_{2} \mathrm{O}\right)_{4} \mathrm{Cl}_{4}\right]} \\
{ }^{-} \mathrm{C}_{2} \mathrm{H}_{5} \mathrm{OH}\end{array}$ & Brown & 320 & 42 & 5.1 & 0.14 & $\begin{array}{c}18.0 \\
(18.1) \\
\end{array}$ & $\begin{array}{c}4.9 \\
(4.2)\end{array}$ & $\begin{array}{c}16.9 \\
(16.6) \\
\end{array}$ & $\begin{array}{l}10.0 \\
(9.6)\end{array}$ & $\begin{array}{c}18.0 \\
(17.7)\end{array}$ & $\begin{array}{l}21.0 \\
(21.4)\end{array}$ \\
\hline$\left[\mathrm{Ni}_{2}(\mathrm{BATl}) \mathrm{Cl}_{4}\right] \cdot \mathrm{H}_{2} \mathrm{O}$ & Grassy green & $>350$ & 61 & 6.3 & 0.12 & $\begin{array}{c}11.0 \\
(11.5) \\
\end{array}$ & $\begin{array}{c}2.2 \\
(1.9)\end{array}$ & $\begin{array}{c}21.9 \\
(21.5) \\
\end{array}$ & $\begin{array}{c}3.5 \\
(3.1) \\
\end{array}$ & $\begin{array}{c}22.9 \\
(22.5)\end{array}$ & $\begin{array}{l}27.0 \\
(27.2)\end{array}$ \\
\hline $\begin{array}{c}\left.\mathrm{Ni}_{2}(\mathrm{BAT} 2)\left(\mathrm{H}_{2} \mathrm{O}\right)_{4} \mathrm{Cl}_{4}\right] \\
\cdot 3 / 4 \mathrm{H}_{2} \mathrm{O} \cdot \mathrm{C}_{2} \mathrm{H}_{5} \mathrm{OH} \\
\end{array}$ & Light green & $>350$ & 48 & 6.1 & 0.29 & \begin{tabular}{c|}
14.9 \\
$(14.8)$ \\
\end{tabular} & $\begin{array}{c}3.4 \\
(3.9) \\
\end{array}$ & $\begin{array}{c}17.6 \\
(17.3) \\
\end{array}$ & $\begin{array}{c}9.3 \\
(9.9) \\
\end{array}$ & $\begin{array}{c}18.2 \\
(17.9) \\
\end{array}$ & $\begin{array}{l}22.0 \\
(21.9) \\
\end{array}$ \\
\hline $\begin{array}{c}\left.\mathrm{Ni}_{2}(\mathrm{BAT} 3)\left(\mathrm{H}_{2} \mathrm{O}\right)_{4} \mathrm{Cl}_{4}\right] \\
\cdot \mathrm{H}_{2} \mathrm{O} \cdot 1 / 5 \mathrm{C}_{2} \mathrm{H}_{5} \mathrm{OH} \\
\end{array}$ & Grassy green & $>350$ & 61 & 6.0 & 0.37 & \begin{tabular}{c|}
14.5 \\
$(14.1)$ \\
\end{tabular} & $\begin{array}{c}3.8 \\
(3.7) \\
\end{array}$ & $\begin{array}{c}18.0 \\
(17.8) \\
\end{array}$ & $\begin{array}{c}9.9 \\
(10.2) \\
\end{array}$ & $\begin{array}{c}18.1 \\
(18.6) \\
\end{array}$ & $\begin{array}{c}22.1 \\
(22.5) \\
\end{array}$ \\
\hline $\begin{array}{c}{\left[\mathrm{Ni}_{2}(\mathrm{BAT} 4)\left(\mathrm{H}_{2} \mathrm{O}_{4} \mathrm{Cl}_{4}\right]\right.} \\
\cdot 1 / 2 \mathrm{H}_{2} \mathrm{O} \cdot 1 / 2 \mathrm{C}_{2} \mathrm{H}_{5} \mathrm{OH}\end{array}$ & Grassy green & $>350$ & 39 & 5.9 & 0.13 & \begin{tabular}{c|}
16.9 \\
$(16.6)$ \\
\end{tabular} & $\begin{array}{c}3.8 \\
(4.0)\end{array}$ & $\begin{array}{c}17.9 \\
(17.3) \\
\end{array}$ & $\begin{array}{c}9.3 \\
(9.9) \\
\end{array}$ & $\begin{array}{c}18.7 \\
(18.1)\end{array}$ & $\begin{array}{c}22.2 \\
(21.8)\end{array}$ \\
\hline $\begin{array}{c}{\left[\mathrm{Cu}_{2}(\mathrm{BATl}) \mathrm{Cl}_{4}\right]} \\
.3 / 2 \mathrm{H}_{2} \mathrm{O}\end{array}$ & Dark brawn & $>350$ & 75 & 9.2 & 0.12 & $\begin{array}{c}10.9 \\
(11.0)\end{array}$ & $\begin{array}{c}1.8 \\
(2.0)\end{array}$ & $\begin{array}{c}19.8 \\
(20.3)\end{array}$ & $\begin{array}{c}11.9 \\
(11.9)\end{array}$ & $\begin{array}{c}24.0 \\
(23.5)\end{array}$ & $\begin{array}{l}26.5 \\
(26.3)\end{array}$ \\
\hline $\begin{array}{c}{\left[\mathrm{Cu}_{2}\left(\mathrm{CBAT}_{4}\right) \mathrm{Cl}_{4}\right]} \\
\cdot 5 / 2 \mathrm{H}_{2} \mathrm{O}\end{array}$ & Dark brawn & 242 & 72 & 9.6 & 0.19 & \begin{tabular}{c|}
12.2 \\
$(12.6)$ \\
\end{tabular} & $\begin{array}{c}2.9 \\
(2.6)\end{array}$ & \begin{tabular}{c|}
19.8 \\
$(19.6)$ \\
\end{tabular} & $\begin{array}{c}11.5 \\
(11.2)\end{array}$ & $\begin{array}{c}22.0 \\
(22.2)\end{array}$ & $\begin{array}{l}25.0 \\
(24.8)\end{array}$ \\
\hline $\begin{array}{c}{\left[\mathrm{Cu}_{2}(\mathrm{BAT} 3)\left(\mathrm{H}_{2} \mathrm{O}\right)_{4} \mathrm{Cl}_{4}\right]} \\
\cdot 3 / 2 \mathrm{H}_{2} \mathrm{O} \cdot 1 / 4 \mathrm{C}_{2} \mathrm{H}_{5} \mathrm{OH}\end{array}$ & Dark brawn & $>350$ & 85 & 10.5 & 0.35 & \begin{tabular}{c|}
13.5 \\
$(13.8)$ \\
\end{tabular} & $\begin{array}{c}3.5 \\
(3.8)\end{array}$ & $\begin{array}{c}16.9 \\
(17.2) \\
\end{array}$ & $\begin{array}{l}10.0 \\
(9.8)\end{array}$ & $\begin{array}{c}19.6 \\
(19.5) \\
\end{array}$ & $\begin{array}{l}21.9 \\
(21.9)\end{array}$ \\
\hline $\begin{array}{c}{\left[\mathrm{Cu}_{2}(\mathrm{BAT} 4)\left(\mathrm{H}_{2} \mathrm{O}\right)_{4} \mathrm{Cl}_{4}\right]} \\
\cdot 1 / 4 \mathrm{H}_{2} \mathrm{O}\end{array}$ & Dark brawn & 260 & 50 & 10.9 & 0.12 & $\begin{array}{c}15.1 \\
(15.2) \\
\end{array}$ & $\begin{array}{c}3.4 \\
(3.6)\end{array}$ & $\begin{array}{c}17.2 \\
(17.7) \\
\end{array}$ & $\begin{array}{c}9.9 \\
(10.1)\end{array}$ & $\begin{array}{c}20.3 \\
(20.1)\end{array}$ & $\begin{array}{c}22.2 \\
(22.5)\end{array}$ \\
\hline
\end{tabular}

$\mathrm{R}_{\mathrm{f}}=$ retention factor in Thin Layer Chromatography

gen and sulfur analysis were determined microanalytically using a Vario EL Fab. CHNS Nr.11042023 instrument. Thin Layer Chromatography (TLC) was carried out on Silica Gel $\mathrm{GF}_{254}$ plates (mn-kieselgel G., $0.2 \mathrm{~mm}$ thickness) with a 3:1 v/v ethylacetate / petroleum ether solution as eluent. The plates were scanned under ultraviolet light $254 \mathrm{~nm}$ lamp [21].

The molar conductance of $10^{-3} \mathrm{M}$ solutions of the ligands and their metal complexes in DMF solvent were measured on a $\mathrm{HACH}$ conductivity meter model sens ion 5 . All the measurements were taken at room temperature on freshly prepared solutions.

The electronic spectra of the ligands and their complexes were recorded in nujol mulls in the range 200-1100 $\mathrm{nm}$ on a Perkin Elmer Lambda $35 \mathrm{UV} / \mathrm{Vis}$ spectrometer. IR spectra of these compounds were recorded on Shimadzu DR-8001 infrared spectrophotometer in $\mathrm{KBr}$ pellets.
Magnetic susceptibility measurements of the solid complexes were carried out at room temperature using a Johnson Metthey and Sherwood magnetic susceptibility balance, and the data collected were processed in accordance with an earlier report [22]. Diamagnetic corrections were carried out using standard Pascal's constants.

Thermogravimetric Analysis (TGA) experiment was conducted using TGA-50H thermal analyzers. All experiments were performed using a single use top loading platinum sample pan under nitrogen atmosphere at a flow rate of $30 \mathrm{ml} / \mathrm{min}$ and a $10^{\circ} \mathrm{C} / \mathrm{min}$ heating rate in the temperature range $25-800^{\circ} \mathrm{C}$. The data were extracted from the TG curves for each decomposition step with the assistance of the DTG curves and hence kinetic parameters of decomposition were evaluated using the Coats-Redfern method [15], as appropriate. 


\section{Biological screening}

The ligands and their metal complexes were tested for their antimicrobial activity against four species of bacteria (Staphylococcus aureus, Streptococcus pyogenes, Haemophilus influenzae, Pseudomonas aeruginosa), and two fungal species (Aspergillus flavus and Candida albicans) using filter paper disc method [23].The diameters of inhibition zones $(\mathrm{mm})$ were measured at the end of an incubation period of 24 hours at $37^{\circ} \mathrm{C}$ for bacteria, and 4 days at $28^{\circ} \mathrm{C}$ for fungi. Discs saturated with DMSO are used as solvent control. Ampicillin 25 $\mu \mathrm{g} / \mathrm{ml}$ was used as a reference substance for bacteria and $30 \mu \mathrm{g} / \mathrm{ml}$ Mycostatin for fungi $[6,21]$.

\section{Results and discussion}

Table 1 compares the elemental analysis, molar conductance and some other physical properties of the BATs ligands and their metals complexes under investigation. The prepared metals complexes show single spots on their thin layer chromatography with satisfactory $\mathrm{R}_{\mathrm{f}}$ values (Table 1), indicating their purity [24]. All the complexes are colored, quite stable in atmospheric conditions and insoluble in water and ethanol, but most of them are partially soluble in acetone, Chloroform, Carbon tetrachloride, DMF and DMSO. Most of the complexes have high melting points $\left(>350^{\circ} \mathrm{C}\right)$ and do not melt but decompose at higher temperature. However, few of them melt and their melting points appear at the $242-320^{\circ} \mathrm{C}$ range.

The proposed empirical formulae of the complexes are in good agreement with the stoichiometry of 2:1, metal : ligand concluded from their analytical data (Table 1) and the thermogravimetric analysis results (Tables 4 and 5). The molar conductance values (Table 1) of $10^{-3} \mathrm{M}$ solutions in DMF solvent are in the range of $3.7-10.9 \mathrm{mS}$ $\mathrm{cm}^{2} \mathrm{~mol}^{-1}$, indicating a non-electrolytic behavior of these metal complexes and clearly suggest the coordination of the anions with the metal ions [25]. The ligands and their metal ions complexes are characterized by elemental analysis, molar conductance, IR spectra, electronic spectra, magnetic susceptibility and with assistance of thermal analysis (Tables 1-5).

\section{Infrared spectra studies}

Table 2 shows the significant IR absorp-

Table 2. Significant IR spectral bands $\left(\mathrm{cm}^{-1}\right)$ of the BATs and their metal complexes

\begin{tabular}{|c|c|c|c|c|c|c|c|c|c|c|c|c|c|c|}
\hline \multirow{2}{*}{ Compound } & \multirow{2}{*}{$v\left(\mathrm{NH}_{2}\right)$} & \multirow{2}{*}{$\begin{array}{c}v(\mathrm{OH}) \\
\mathrm{H}_{2} \mathrm{O}\end{array}$} & \multirow{2}{*}{ vCH-aliph. } & \multirow{2}{*}{$v(\mathrm{C}=\mathrm{N})$} & \multirow{2}{*}{$v(\mathrm{C}=\mathrm{S})$} & \multirow{2}{*}{$v(\mathrm{~N}-\mathrm{N})$} & \multicolumn{4}{|c|}{ Thioamide Bands } & \multirow{2}{*}{$v(\mathrm{M}-\mathrm{O})$} & \multirow{2}{*}{$v(\mathrm{M}-\mathrm{N})$} & \multirow{2}{*}{$v(\mathrm{M}-\mathrm{S})$} & \multirow{2}{*}{$v(\mathrm{M}-\mathrm{Cl})$} \\
\hline & & & & & & & I & II & III & IV & & & & \\
\hline BAT1 & $\begin{array}{l}3308, \\
3204 \\
\end{array}$ & - & 2955 & 1622 & 1244 & 1044 & 1581 & 1302 & 982 & 750 & - & - & - & - \\
\hline$\left[\mathrm{Co}_{2}(\mathrm{BATl}) \mathrm{Cl}_{4}\right] \cdot \mathrm{H}_{2} \mathrm{O} \cdot 1 / 3 \mathrm{C}_{2} \mathrm{H}_{5} \mathrm{OH}$ & 3225 & 3391 & 2955 & 1564 & 1227 & 924 & 1564 & 1294 & 924 & 695 & 426 & 406 & 350 & 347 \\
\hline$\left[\mathrm{Ni}_{2}(\mathrm{BAT1}) \mathrm{Cl}_{4}\right] \cdot \mathrm{H}_{2} \mathrm{O}$ & 3225 & 3433 & 2955 & 1514 & 1217 & 928 & 1564 & 1294 & 928 & 675 & 426 & 405 & 350 & \\
\hline$\left[\mathrm{Cu}_{2}(\mathrm{BATl}) \mathrm{Cl}_{4}\right] \cdot 1 \frac{1}{2} \mathrm{H}_{2} \mathrm{O}$ & $\begin{array}{l}3287, \\
3163 \\
\end{array}$ & 3454 & 2955 & 1514 & 1228 & 928 & 1568 & 1294 & 928 & 675 & - & 405 & 350 & 347 \\
\hline BAT2 & $\begin{array}{l}3308, \\
3277 \\
\end{array}$ & - & 2948 & 1621 & 1253 & 1032 & 1570 & 1319 & 970 & 781 & - & - & - & - \\
\hline$\left[\mathrm{Co}_{2}(\mathrm{BAT} 2) \mathrm{Cl}_{4}\right]^{3} \cdot 3 / 4 \mathrm{H}_{2} \mathrm{O} \cdot 1 / 2 \mathrm{C}_{2} \mathrm{H}_{5} \mathrm{OH}$ & 3225 & 3391 & 2976 & 1617 & 1232 & 950 & 1560 & 1314 & 930 & 692 & 476 & 402 & 350 & 340 \\
\hline$\left[\mathrm{Ni}_{2}(\mathrm{BAT} 2)\left(\mathrm{H}_{2} \mathrm{O}\right)_{4} \mathrm{Cl}_{4}\right]^{-3 / 4} \mathrm{H}_{2} \mathrm{O} \cdot \mathrm{C}_{2} \mathrm{H}_{5} \mathrm{OH}$ & $\begin{array}{l}3267, \\
3163\end{array}$ & 3412 & 2935 & 1568 & 1165 & 970 & 1568 & 1317 & 974 & 742 & 435 & 405 & 352 & 329 \\
\hline$\left[\mathrm{Cu}_{2}\left(\mathrm{BAT}_{2}\right) \mathrm{Cl}_{4}\right] \cdot 2^{1} \frac{1}{2} \mathrm{H}_{2} \mathrm{O}$ & $\begin{array}{l}3287, \\
3184\end{array}$ & 3454 & 2934 & 1611 & 1215 & 974 & 1558 & 1318 & 974 & 742 & 440 & 400 & 351 & 325 \\
\hline BAT3 & $\begin{array}{l}3308, \\
3267\end{array}$ & - & 2934 & 1626 & 1248 & 1028 & 1581 & 1327 & 982 & 745 & - & - & - & - \\
\hline$\left[\mathrm{CO}_{2}(\mathrm{BAT} 3)\left(\mathrm{H}_{2} \mathrm{O}\right)_{4} \mathrm{Cl}_{4}\right]^{1 / 1 / 4} \mathrm{H}_{2} \mathrm{O} \cdot 1 / 3 \mathrm{C}_{2} \mathrm{H}_{5} \mathrm{OH}$ & 3204 & 3391 & 2934 & 1622 & 1232 & 992 & 1547 & 1311 & 980 & 692 & 480 & 400 & 351 & 347 \\
\hline$\left[\mathrm{Ni}_{2}(\mathrm{BAT} 3)\left(\mathrm{H}_{2} \mathrm{O}\right)_{4} \mathrm{Cl}_{4}\right] \cdot \mathrm{H}_{2} \mathrm{O} \cdot 1 / 5 \mathrm{C}_{2} \mathrm{H}_{5} \mathrm{OH}$ & 3184 & 3412 & 2955 & 1622 & 1231 & 982 & 1514 & 1323 & 982 & 692 & 430 & 400 & 355 & 334 \\
\hline$\left[\mathrm{Cu}_{2}(\mathrm{BAT} 3)\left(\mathrm{H}_{2} \mathrm{O}\right)_{4} \mathrm{Cl}_{4}\right] \cdot 1 \frac{1}{2} \mathrm{H}_{2} \mathrm{O} \cdot 1 / 4 \mathrm{C}_{2} \mathrm{H}_{5} \mathrm{OH}$ & $\begin{array}{l}3287, \\
3184 \\
\end{array}$ & 3474 & 2955 & 1622 & 1232 & 974 & 1558 & 1323 & 974 & 675 & 427 & 405 & 384 & 359 \\
\hline BAT4 & $\begin{array}{l}3308, \\
3204\end{array}$ & - & 2955 & 1622 & 1240 & 1027 & 1581 & 1323 & 920 & 754 & - & - & - & - \\
\hline$\left[\mathrm{Co}_{2}(\mathrm{BAT} 4)\left(\mathrm{H}_{2} \mathrm{O}\right)_{4} \mathrm{Cl}_{4}\right] \cdot \mathrm{C}_{2} \mathrm{H}_{5} \mathrm{OH}$ & $\begin{array}{l}3204, \\
3142 \\
\end{array}$ & 3427 & 2934 & 1564 & 1232 & 995 & 1564 & 1323 & 908 & 737 & 426 & 405 & 385 & 355 \\
\hline$\left[\mathrm{Ni}_{2}(\mathrm{BAT} 4)\left(\mathrm{H}_{2} \mathrm{O}\right)_{4} \mathrm{Cl}_{4}\right]^{1 / 2} \mathrm{H}_{2} \mathrm{O} \cdot 1 / 2 \mathrm{C}_{2} \mathrm{H}_{5} \mathrm{OH}$ & 3225 & 3371 & 2934 & 1615 & 1230 & 1000 & 1547 & 1323 & 905 & 735 & 426 & 405 & 382 & 341 \\
\hline$\left[\mathrm{Cu}_{2}(\mathrm{BAT} 4)\left(\mathrm{H}_{2} \mathrm{O}\right)_{4} \mathrm{Cl}_{4}\right]^{1 / 4} / 4 \mathrm{H}_{2} \mathrm{O}$ & $\begin{array}{l}3308, \\
3184 \\
\end{array}$ & 3412 & 2934 & 1613 & 1229 & 1000 & 1541 & 1323 & 909 & 735 & 426 & 405 & 380 & 355 \\
\hline
\end{tabular}


tion bands of the BATs ligands and their twelve complexes. The IR spectra of BAT1, BAT2, BAT3 and BAT4 accord with the literature [7]. A broad IR band in the range $3142-3474 \mathrm{~cm}^{-1}$ in the complexes is attributed to the overlapping vibration of $v \mathrm{NH}\left(\mathrm{NH}_{2}\right)$ with that of $v \mathrm{OH}\left(\mathrm{H}_{2} \mathrm{O}\right)$ of coordinated water [26]. Coordinated water shows metal-oxygen $v(\mathrm{M}-\mathrm{O})$ stretching vibration in the $426-480 \mathrm{~cm}^{-1}$ [27].

The appearance of the four thioamide bands (I-IV) at 1570 - 1581, 1302 - 1327, 920 982 and $745-781 \mathrm{~cm}^{-1}$ [27], refutes the presence of the bands in the $2400-2600 \mathrm{~cm}^{-1}$ regions and at $606 \mathrm{~cm}^{-1}$ due to $v(\mathrm{SH})$ and $v(\mathrm{C}-\mathrm{S})$, respectively [28] confirming that the ligands of BATs exist mainly in the thione form [5].These four thioamide bands of the ligands are compared with those of their complexes in Table 2, indicating the shift due to complexation. The bands at 1240$1253 \mathrm{~cm}^{-1}$ in the spectra of the ligands assigned to $v(\mathrm{C}=\mathrm{S})$ is lowered by $8-88 \mathrm{~cm}^{-1}$ in the spectra of the complexes, indicating involvement of thione groups sulfur in the coordination. This leads to new bands in the region $350-385 \mathrm{~cm}^{-1}$ tentatively assigned to $\mathrm{M}-\mathrm{S}$ vibration [27].

The shift to lower frequency of the amino group by $20-124 \mathrm{~cm}^{-1}$ may suggest the participation of the nitrogen atom in the complexation. The bands at $1027-1044 \mathrm{~cm}^{-1}$ due to $v(\mathrm{~N}-\mathrm{N})$ in the free ligands are shifted to lower frequencies by $27-120 \mathrm{~cm}^{-1}$ in the complexes formation spectra [29], confirming the coordination through the nitrogen atoms . In addition, the shift in $v(\mathrm{C}=\mathrm{N})$, for $\mathrm{C}=\mathrm{N}$ being adjacent to $\mathrm{N}-\mathrm{N}$ in the molecular structure, is to lower frequency by $4-108 \mathrm{~cm}^{-1}$ [13]. Coordination through the amino groups nitrogen is consistent with new bands in the 400$406 \mathrm{~cm}^{-1}$, assignable to the $v(\mathrm{M}-\mathrm{N})$ vibration [23, $27,30]$. The new band at the low frequency $325-$ $359 \mathrm{~cm}^{-1}$ is assigned to $v(\mathrm{M}-\mathrm{Cl})$. The above findings indicate the tetradentate $(\mathrm{N}$ and $\mathrm{S}$ donor atoms) nature of ligands, enhancing the coordination of two metal ions with one ligand molecule.

\section{Electronic and magnetic studies}

Table 3 compares the magnetic moments, electronic spectral data and ligand field parameters of the $\mathrm{Co}(\mathrm{II}), \mathrm{Ni}(\mathrm{II})$ and $\mathrm{Cu}(\mathrm{II})$ complexes with the ligands of BATs. The electronic spectrum of the ligands BAT2 and BAT3 exhibit their two absorption maxima in the ranges 42194 $33333 \mathrm{~cm}^{-1}$ and $42373-33112 \mathrm{~cm}^{-1}$, assignable to $\pi \rightarrow \pi^{*}$ (K-band) and $\mathrm{n} \rightarrow \pi^{*}$ (R-band) transitions [27], respectively, (Table 3).

From the electronic spectra and magnetic moment data the structures and geometries of these $\mathrm{Co}(\mathrm{II}), \mathrm{Ni}(\mathrm{II})$ and $\mathrm{Cu}(\mathrm{II})$ complexes are identified and interpreted, as illustrated in structures I and II and given in Table (3). The electronic spectrum of the $\mathrm{Co}(\mathrm{II})$ complexes,

Table 3. Magnetic moment, electronic spectral data in Nujol mull and ligand field parameters for the BATs and their Complexes.

\begin{tabular}{|c|c|c|c|c|c|c|c|c|c|c|c|}
\hline \multirow{2}{*}{ Compound } & \multirow{2}{*}{$\begin{array}{c}\mu_{\text {eff }} \\
\text { (B.M.) }\end{array}$} & \multicolumn{2}{|c|}{ UV bands $\left(\mathrm{cm}^{-1}\right)$} & \multirow{2}{*}{$\begin{array}{l}\mathrm{L} \rightarrow \mathrm{M} \\
\text { charge } \\
\text { transfer } \\
\left(\mathrm{cm}^{-1}\right)\end{array}$} & \multirow{2}{*}{$\begin{array}{l}d d \text { transition bands } \\
\left(\mathrm{cm}^{-1}\right)\end{array}$} & \multirow{2}{*}{$\begin{array}{c}v_{1} \\
\left(\mathrm{~cm}^{-1}\right)\end{array}$} & \multicolumn{4}{|c|}{ Ligand field parameters } & \multirow{2}{*}{$\begin{array}{l}\text { Supposed } \\
\text { structure }\end{array}$} \\
\hline & & $\pi \rightarrow \pi^{*}$ & $\mathrm{n} \rightarrow \pi^{*}$ & & & & $\begin{array}{c}B \\
\left(\mathrm{~cm}^{-1}\right)\end{array}$ & $\beta$ & $\begin{array}{l}10 D q \\
\left(\mathrm{~cm}^{-1}\right)\end{array}$ & $v_{2} / v_{1}$ & \\
\hline BAT2 & - & 42194 & 33333 & - & - & - & - & - & - & - & - \\
\hline$\left[\mathrm{Co}_{2}(\mathrm{BAT} 2) \mathrm{Cl}_{4}\right]^{3} \cdot 3 / 4 \mathrm{H}_{2} \mathrm{O} \cdot 1 / 2 \mathrm{C}_{2} \mathrm{H}_{5} \mathrm{OH}$ & 2.10 & 44053 & - & $23041^{\mathrm{b}}$ & $\begin{array}{c}20000,16779,14881 \\
, 12255 \\
\end{array}$ & - & - & - & - & - & $\begin{array}{l}\text { Square } \\
\text { planer }\end{array}$ \\
\hline$\left[\mathrm{Ni}_{2}(\mathrm{BAT} 2)\left(\mathrm{H}_{2} \mathrm{O}\right)_{4} \mathrm{Cl}_{4}\right]^{3 / 3} / 4 \mathrm{H}_{2} \mathrm{O} \cdot \mathrm{C}_{2} \mathrm{H}_{5} \mathrm{OH}$ & 3.08 & 40161 & 33333 & $28409^{\mathrm{b}}$ & $22831,18797,14245$ & 9901 & 795 & 0.76 & 9901 & 1.89 & Octahedral \\
\hline$\left[\mathrm{Cu}_{2}(\mathrm{BAT} 2) \mathrm{Cl}_{4}\right] \cdot 2 \frac{1}{2} \mathrm{H}_{2} \mathrm{O}$ & 1.41 & 41152 & 33300 & $\begin{array}{l}28421^{\circ}, \\
25126^{\circ} \\
20661^{b}\end{array}$ & 16778 & - & - & - & - & - & $\begin{array}{l}\text { Square } \\
\text { planar }\end{array}$ \\
\hline ВАТЗ & - & 42373 & 33112 & - & - & - & - & - & - & - & - \\
\hline$\left[\mathrm{Co}_{2}(\mathrm{BAT} 3)\left(\mathrm{H}_{2} \mathrm{O}\right)_{4} \mathrm{Cl}_{4}\right]^{1 / 1 / 4} \mathrm{H}_{2} \mathrm{O} \cdot 1 / 3 \mathrm{C}_{2} \mathrm{H}_{5} \mathrm{OH}$ & 4.27 & 39370 & 33113 & $25000^{\mathrm{b}}$ & 19231,14837 & 6948 & 889 & 0.92 & 7889 & 2.14 & Octahedral \\
\hline$\left[\mathrm{Ni}_{2}(\mathrm{BAT} 3)\left(\mathrm{H}_{2} \mathrm{O}\right)_{4} \mathrm{Cl}_{4}\right] \cdot \mathrm{H}_{2} \mathrm{O} \cdot 1 / 5 \mathrm{C}_{2} \mathrm{H}_{5} \mathrm{OH}$ & 2.86 & 39370 & 33113 & $27855^{\mathrm{b}}$ & $25000,18382,14577$ & 8767 & 885 & 0.85 & 8767 & 1.66 & Octahedral \\
\hline$\left[\mathrm{Cu}_{2}(\mathrm{BAT} 3)\left(\mathrm{H}_{2} \mathrm{O}\right)_{4} \mathrm{Cl}_{4}\right] \cdot 1 \frac{1}{2} \mathrm{H}_{2} \mathrm{O}^{1 / 1} / 4 \mathrm{C}_{2} \mathrm{H}_{5} \mathrm{OH}$ & 1.45 & 41841 & 33112 & $\begin{array}{l}28409, \\
24876, \\
21736,\end{array}$ & 18797,13736 & - & - & - & - & - & $\begin{array}{c}\text { Distorted } \\
\text { Octahedral }\end{array}$ \\
\hline
\end{tabular}

a: $\mathrm{O} \rightarrow \mathrm{M}$ Charge transfer $, \mathrm{b}: \mathrm{S} \rightarrow \mathrm{M}$ Charge transfer, $\mathrm{c}: \mathrm{d} \rightarrow \pi^{*}$ Charge transfer. 
$\left[\mathrm{Co}_{2}(\mathrm{BAT} 3)\left(\mathrm{H}_{2} \mathrm{O}\right)_{4} \mathrm{Cl}_{4}\right] \cdot 1 / 4 \mathrm{H}_{2} \mathrm{O} \cdot 1 / 3 \mathrm{C}_{2} \mathrm{H}_{5} \mathrm{OH}$ is indicated by the absorption bands at $19231 \mathrm{~cm}^{-1}$ and $14837 \mathrm{~cm}^{-1}$ due to the ${ }^{4} T_{1 \mathrm{~g}} \rightarrow{ }^{4} T_{1 \mathrm{~g}}(P)\left(v_{3}\right)$ and ${ }^{4} T_{1 \mathrm{~g}} \rightarrow{ }^{4} A_{2 \mathrm{~g}}\left(v_{2}\right)$ transitions [31], respectively, suggesting octahedral geometry (structure I).

Due to instrumental limitation, the values of $v_{2}$ and $v_{3}$ obtained from the electronic spectra are used to calculate the third transition, ${ }^{4} T_{1 \mathrm{~g}} \rightarrow{ }^{4} T_{2 \mathrm{~g}}(F)\left(v_{1}\right)$ band by the equations used for the $d^{7}$ system [32] and found to be $6948 \mathrm{~cm}^{-1}$. From these transition bands the ligands field parameters (Table 3) calculated for the $\mathrm{Co}(\mathrm{II})$ complex of BAT3 ligand are $B=889 \mathrm{~cm}^{-1}, \beta=$ $0.92,10 D q=7889 \mathrm{~cm}^{-1}$ and $v_{2} / v_{1}=2.14$, respectively. Reduction of the $B$ value of the free ion from $971 \mathrm{~cm}^{-1}$ to $889 \mathrm{~cm}^{-1}$ (i.e. $\beta$ from 1 to 0.92 ) on the complexation indicates the covalent character of metal-to-ligand bonds [33]. The lower is the value the greater is the covalency.

The $\mathrm{Co}(\mathrm{II})$ complexes, $\left[\mathrm{Co}_{2}\right.$ (BAT3) $\left.\left.\left(\mathrm{H}_{2} \mathrm{O}\right)_{4} \mathrm{Cl}_{4}\right] \cdot 1 / 4 \mathrm{H}_{2} \mathrm{O} \cdot 1 / 3 \mathrm{C}_{2} \mathrm{H}_{5} \mathrm{OH}\right]$ and $\mathrm{Co}_{2}(\mathrm{BAT} 4)$ $\left.\left(\mathrm{H}_{2} \mathrm{O}\right)_{4} \mathrm{Cl}_{4}\right] \cdot \mathrm{C}_{2} \mathrm{H}_{5} \mathrm{OH}$ have magnetic moments of 4.27 and 4.82 B.M., respectively, which lie in the range reported [34] for an octahedral geometry around the $\mathrm{Co}(\mathrm{II})$ ion (structure I). However, the subnormal magnetic moments of the Co(II) chelates reflect a behavior of the binuclear complexes [30]. The 4.27 B.M. value is lower than that previously reported [35]. However, magnetic moments lower than 4.80 B.M for the octahedral Co(II) complexes has been observed [36]. The anomalous magnetic moment suggests a lowsymmetry around the cobalt (II) ion [37]. Moreover, the gray and brown colors of the complexes are in good agreement with those reported for octahedral $\mathrm{Co}$ (II) complexes [33].

The observed charge transfer band recorded for the complex of BAT3 at $25,000 \mathrm{~cm}^{-1}$ is mainly due to $\mathrm{S} \rightarrow \mathrm{Co}[27,32]$. This charge transfer transitions probably from the $\pi$-orbitals of the donor atoms to the metal ion. The UV bands, $\pi \rightarrow$ $\pi^{*}$ and $n \rightarrow \pi^{*}$, of the ligand most likely moves to lower energy on complexation [29].

The other $\mathrm{Co}(\mathrm{II})$ complexes, $\left[\mathrm{Co}_{2}(\mathrm{BAT} 1)\right.$ $\left.\mathrm{Cl}_{4}\right] \cdot \mathrm{H}_{2} \mathrm{O} \cdot 1 / 3 \mathrm{C}_{2} \mathrm{H}_{5} \mathrm{OH}$ and

$\left[\mathrm{Co}_{2}(\mathrm{BAT} 2) \mathrm{Cl}_{4}\right] \cdot 3 / 4 \mathrm{H}_{2} \mathrm{O} \cdot 1 / 2 \mathrm{C}_{2} \mathrm{H}_{5} \mathrm{OH}$ have a magnetic moments (2.67 and 2.10 B.M, respectively) which fall in the region reported for one unpaired electron existing in both square-planer and low spin octahedral geometries [27]. The absence of octahedral characteristic bands spectra excludes the low spin octahedral configuration, whereas the existence of a broad band at 20,000 $\mathrm{cm}^{-1}$ in the $\left[\mathrm{Co}_{2}(\mathrm{BAT} 2) \mathrm{Cl}_{4}\right] \cdot 3 / 4 \mathrm{H}_{2} \mathrm{O} \cdot 1 / 2 \mathrm{C}_{2} \mathrm{H}_{5} \mathrm{OH}$ electronic spectrum may suggest a square-planer geometry (structure II). Also, the existence of the three bands at $12,255,14,881$ and $16,779 \mathrm{~cm}^{-1}$ confirms the proposed geometry [27, 32]. These observations together with the magnetic moment value (2.10 B.M.) support the presence of a square planar environment around the cobalt (II) ion [32].

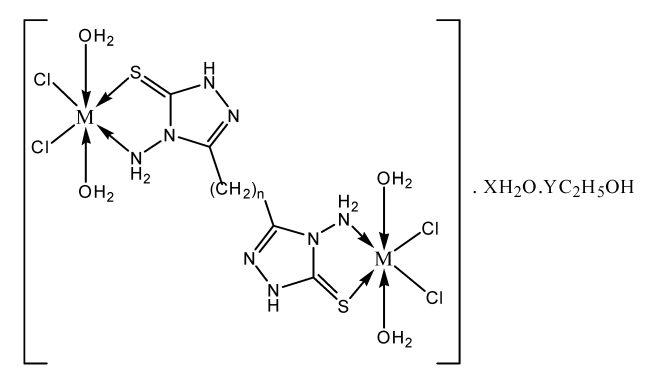

$\mathrm{M}=\mathrm{Co}^{2+}: \mathrm{n}=3,4 ; \mathrm{X}=0.25,0 ; \mathrm{Y}=0.33,1$

$\mathrm{M}=\mathrm{Ni}^{2+}: \mathrm{n}=2,3,4 ; \mathrm{X}=0.75,1,0.5 ; \mathrm{Y}=1,0.2,0.5$

$\mathrm{M}=\mathrm{Cu}^{2+}: \mathrm{n}=3,4 ; \mathrm{X}=1.5,0.25 ; \mathrm{Y}=0.25,0$

\section{Structure I}

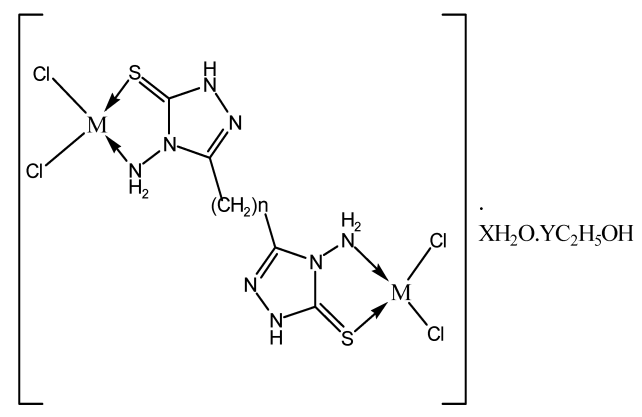

$\mathrm{M}=\mathrm{Co}^{2+}: \mathrm{n}=1,2 ; \mathrm{X}=1,0.75 ; \mathrm{Y}=0.33,0.5$

$\mathrm{M}=\mathrm{Ni}^{2+}: \mathrm{n}=1 ; \mathrm{X}=1 ; \mathrm{Y}=0$

$\mathrm{M}=\mathrm{Cu}^{2+}: \mathrm{n}=1,2 ; \mathrm{X}=1.5,2.25 ; \mathrm{Y}=0,0$

\section{Structure II}

Nickel(II) complexes

The complexes $\left[\mathrm{Ni}_{2}(\mathrm{BAT} 2)\left(\mathrm{H}_{2} \mathrm{O}\right)_{4} \mathrm{Cl}_{4}\right]$ $\left.\cdot 3 / 4 \mathrm{H}_{2} \mathrm{O} \cdot \mathrm{C}_{2} \mathrm{H}_{5} \mathrm{OH}\right],\left[\mathrm{Ni}_{2}(\mathrm{BAT} 3)\left(\mathrm{H}_{2} \mathrm{O}\right)_{4} \mathrm{Cl}_{4}\right] \cdot \mathrm{H}_{2} \mathrm{O} \cdot$ $1 / 5 \mathrm{C}_{2} \mathrm{H}_{5} \mathrm{OH}$ and $\left[\mathrm{Ni}_{2}(\mathrm{BAT} 4)\left(\mathrm{H}_{2} \mathrm{O}\right)_{4} \mathrm{Cl}_{4}\right] \cdot 1 / 2 \mathrm{H}_{2} \mathrm{O}$. $\left.1 / 2 \mathrm{C}_{2} \mathrm{H}_{5} \mathrm{OH}\right]$ have magnetic moments of 3.08, 2.86 and 3.00 B.M., respectively. They lie in the range 
reported [34] for an octahedral geometry around the $\mathrm{Ni}(\mathrm{II})$ ion with a ${ }^{3} A_{2 \mathrm{~g}}$ ground term (structure I).

The nickel (II) complexes, [ $\mathrm{Ni}_{2}$ (BAT2) $\left.\left(\mathrm{H}_{2} \mathrm{O}\right)_{4} \mathrm{Cl}_{4}\right] \cdot 3 / 4 \mathrm{H}_{2} \mathrm{O} \cdot \mathrm{C}_{2} \mathrm{H}_{5} \mathrm{OH}$ and $\left[\mathrm{Ni}_{2}\right.$ (BAT3) $\left.\left(\mathrm{H}_{2} \mathrm{O}\right)_{4} \mathrm{Cl}_{4}\right] \cdot \mathrm{H}_{2} \mathrm{O} \cdot 1 / 5 \mathrm{C}_{2} \mathrm{H}_{5} \mathrm{OH}$, electronic spectra indicate two absorption bands in the regions 22831-25000 and 14577-18797 $\mathrm{cm}^{-1}$ for $v_{3}$ and $v_{2}$ transitions $\left[{ }^{3} A_{2 \mathrm{~g}} \rightarrow{ }^{3} T_{1 \mathrm{~g}}(P) \quad\left(v_{3}\right)\right.$ and ${ }^{3} A_{2 \mathrm{~g}} \rightarrow$ $\left.{ }^{3} T_{1 \mathrm{~g}}(F)\left(v_{2}\right)\right]$ and the third $v_{1}$ transition $\left[{ }^{3} A_{2 \mathrm{~g}} \rightarrow\right.$ $\left.{ }^{3} T_{2 \mathrm{~g}}\left(v_{1}\right)\right]$ band is estimated $\left(8767-9901 \mathrm{~cm}^{-1}\right)$ using equations for the $d^{8}$ system [32]. These transitions suggest an octahedral geometry (structure I) for Ni (II) complex [31].

The ligand field parameters: $(B=795-885$ $\mathrm{cm}^{-1}, \beta=0.76-0.85,10 D q=8767-9901 \mathrm{~cm}^{-1}$ and $\left.v_{2} / v_{1}=1.66-1.89\right)$ worked out for this complex (Table 3) lie in the same range as reported for an octahedral structure around $\mathrm{Ni}(\mathrm{II})$ ions [32]. Reduction of the $B$ value of the free ion from $1041 \mathrm{~cm}^{-1}$ to $795-885 \mathrm{~cm}^{-1}$ due to complex formation indicates the covalent character of metalto-ligand bonds [33]. The green color of this complex is an additional evidence for an octahedral structure [27].

The $\left[\mathrm{Ni}_{2}(\mathrm{BAT} 1) \mathrm{Cl}_{4}\right] \cdot \mathrm{H}_{2} \mathrm{O}$ complex is diamagnetic, which factually supports (structure II) square-planar geometry [30]. The commonly square-planar $\mathrm{Ni}$ (II) complexes are orange or red but a few have purple or green colors [32].

\section{Copper(II) complexes}

The complexes $\left[\mathrm{Cu}_{2}\right.$ (BAT3) $\left.\left(\mathrm{H}_{2} \mathrm{O}\right)_{4} \mathrm{Cl}_{4}\right] \cdot$ $3 / 2 \mathrm{H}_{2} \mathrm{O} \cdot 1 / 4 \mathrm{C}_{2} \mathrm{H}_{5} \mathrm{OH}$ and $\left[\mathrm{Cu}_{2}\right.$ (BAT4) $\left.\left(\mathrm{H}_{2} \mathrm{O}\right)_{4} \mathrm{Cl}_{4}\right] \cdot$ $1 / 4 \mathrm{H}_{2} \mathrm{O}$ possess magnetic moments (1.45 and 1.58 B.M., respectively) found to be within the range reported for the $d^{9}$-system containing one unpaired electron [38], and assignable to a distorted octahedral geometry (structure I). The dark brown color of these complexes supports the proposed geometry [38].

The electronic spectrum of $\left[\mathrm{Cu}_{2}\right.$ (BAT3) $\left.\left(\mathrm{H}_{2} \mathrm{O}\right)_{4} \mathrm{Cl}_{4}\right] \cdot 3 / 2 \mathrm{H}_{2} \mathrm{O} \cdot 1 / 4 \mathrm{C}_{2} \mathrm{H}_{5} \mathrm{OH}$, show weak shoulders at $18,797 \mathrm{~cm}^{-1}$ and $13,736 \mathrm{~cm}^{-1}$. These bands are due to ${ }^{2} B_{1 \mathrm{~g}} \rightarrow{ }^{2} E_{\mathrm{g}}$ and ${ }^{2} B_{1 \mathrm{~g}} \rightarrow{ }^{2} A_{1 \mathrm{~g}}$ transitions in a distorted octahedral geometry $[30,32]$. The broadness of the observed band may be due to Jahn-Teller effect [39], which enhances the distortion of the octahedral geometry.
The magnetic moments of the $\left[\mathrm{Cu}_{2}(\mathrm{BAT} 1)\right.$ $\left.\mathrm{Cl}_{4}\right] \cdot 3 / 2 \mathrm{H}_{2} \mathrm{O}$ and $\left[\mathrm{Cu}_{2}\left({ }_{4} \mathrm{BAT} 2\right) \mathrm{Cl}_{4}\right] \cdot 5 / 2 \mathrm{H}_{2} \mathrm{O}$ complexes are 1.85 and 1.41 B.M., respectively. These values lie in the range reported [39] for a squareplanar geometry (structure II). The lower value of $\mu_{\text {eff }}(1.45,1.58$ and 1.41 B.M.) than that calculated (1.73B.M.) for one unpaired electron is normal and expected if binuclear complexes are considered [30]. Thus, in general a decrease in the magnetic moment below the spin-only value (1.73B.M.) may be attributed to molecular association taking place to form bi-or poly nuclear molecules [40]. Little changes in the ligands bands $\left(\pi \rightarrow \pi^{*}\right.$ and $\left.n \rightarrow \pi^{*}\right)$ energies are detected on complexation [29]. It is proved that the bands observed at 20661 and 21736 $\mathrm{cm}^{-1}$ are assigned to $\mathrm{S} \rightarrow \mathrm{Cu}$ (II) transition [27], and that at 28421 and $28409 \mathrm{~cm}^{-1}$ may be assigned to $d \rightarrow \pi^{*}[41]$.

\section{Thermal analysis}

Tables 4 and 5 compare the characteristic thermal and kinetic parameters determined for each step in the decomposition sequence of the complexes. It can be seen clearly (Tables 4 and 5) that the mass losses $(\Delta \mathrm{m} \%)$ obtained from the TG curves and that calculated for the corresponding molecule or molecules are in good agreement as is the case for all of these complexes. However, as the compositions of the final decomposition products (i.e. final residues) are not proved, illdefined final states are considered for the thermal decomposition of these six complexes. The integral method used is the Coats-Redfern equation [15] for reaction order $n \neq 1$, which when linearised for a correctly chosen $n$ yields the activation energy from the slope;

$$
\log \left[\frac{1-(1-\alpha)^{1-n}}{T^{2}(1-n)}\right]=\log \frac{Z R}{q E}\left[1-\frac{2 R T}{E}\right]-\frac{E}{2.303 R T}
$$

where: $\alpha=$ fraction of weight loss, $\mathrm{T}=$ temperature $(\mathrm{K}), \mathrm{n}=$ order of reaction, $\mathrm{Z}=$ pre-exponential factor, $\mathrm{R}=$ molar gas constant, $\mathrm{E}_{\mathrm{a}}=$ activation energy and $\mathrm{q}=$ heating rate.

The TGA (TG and DTG) curves recorded for the BAT2 and BAT3 ligands are given in Figure 1.The BAT2 and BAT3 ligands exhibit almost similar thermal decomposition process and the resulting mass loss $(\Delta \mathrm{m} \%)$, order reaction $(n)$, activation energy $\left(\mathrm{E}_{\mathrm{a}}\right)$, initial $\left(\mathrm{T}_{\mathrm{i}}\right)$, final 
Table 4. Characteristic parameters of thermal decomposition $\left(10^{\circ} \mathrm{C} \mathrm{min}^{-1}\right)$ for $\mathrm{Co}(\mathrm{II}), \mathrm{Ni}(\mathrm{II})$ and $\mathrm{Cu}$ (II) complexes of BAT2.

\begin{tabular}{|c|c|c|c|c|c|c|c|c|}
\hline \multirow[b]{2}{*}{ Comp. } & \multirow[b]{2}{*}{ Step } & \multicolumn{4}{|c|}{ TGA } & \multirow[b]{2}{*}{$\mathrm{n}$} & \multirow[b]{2}{*}{$\begin{array}{c}\mathrm{E}_{\mathrm{a}} / \\
\mathrm{kJ} \mathrm{mole}^{-1}\end{array}$} & \multirow[b]{2}{*}{ Reaction } \\
\hline & & $\begin{array}{l}\Delta \mathrm{m} \% \\
\text { found } \\
\text { (calc.) }\end{array}$ & $\mathrm{T}_{\mathrm{i}} /{ }^{\circ} \mathrm{C}$ & $\mathrm{T}_{\mathrm{f}} /{ }^{\circ} \mathrm{C}$ & $\mathrm{T}_{\mathrm{DTG}}$ & & & \\
\hline \multirow{3}{*}{ BAT2 } & 1 & 19 & 130 & 281 & 249 & 1.9 & 234 & - [ $19 \%$ of Ligand] \\
\hline & 2 & 24 & 281 & 410 & 324 & 2.6 & 201 & - [ $24 \%$ of Ligand] \\
\hline & \multicolumn{8}{|c|}{ Total mass loss $=84.5 \%$ and Final residue $=15.5 \%$; at $800{ }^{\circ} \mathrm{C}$} \\
\hline \multirow{6}{*}{ 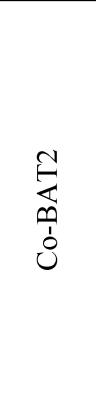 } & 1 & $\begin{array}{c}6.70 \\
(6.60)\end{array}$ & 34 & 153 & 69 & 2.5 & 72 & $-\left[0.5 \mathrm{EtOH}+0.75 \mathrm{H}_{2} \mathrm{O}\right]$ \\
\hline & 2 & $\begin{array}{c}25.70 \\
(25.60) \\
\end{array}$ & 169 & 367 & 267 & 2.2 & 102 & $-4 \mathrm{Cl}$ \\
\hline & 3 & $\begin{array}{c}10.60 \\
(10.70) \\
\end{array}$ & 367 & 499 & 455 & 1.2 & 123 & $-\left[23 \%\right.$ of $\left.b b^{a}\right]$ \\
\hline & 4 & $\begin{array}{c}10.80 \\
(10.70)\end{array}$ & 499 & 648 & 540 & 2.4 & 237 & $-\left[23 \%\right.$ of $\left.b^{a}\right]$ \\
\hline & 5 & $\begin{array}{c}13.00 \\
(13.00)\end{array}$ & 648 & 781 & 718 & 1.2 & 316 & $-\left[28 \%\right.$ of $\left.b^{a}\right]$ \\
\hline & \multicolumn{8}{|c|}{ Final residue $\left(2 \mathrm{Co}+26 \%\right.$ of $\left.b^{\mathrm{a}}\right): 33.20 \%(33.40 \%)$} \\
\hline \multirow{4}{*}{$\begin{array}{l}\stackrel{N}{E} \\
\underset{m}{1} \\
\frac{1}{Z}\end{array}$} & 1 & $\begin{array}{c}14.70 \\
(14.72) \\
\end{array}$ & 33 & 180 & 81 & 2.1 & 53 & $-\left[\mathrm{EtOH}+0.75 \mathrm{H}_{2} \mathrm{O}+2 \mathrm{H}_{2} \mathrm{O}\right]$ \\
\hline & 2 & $\begin{array}{c}22.10 \\
(21.95) \\
\end{array}$ & 180 & 400 & 327 & 1.1 & 53 & $-\left[2 \mathrm{H}_{2} \mathrm{O}+3 \mathrm{Cl}\right]$ \\
\hline & 3 & $\begin{array}{c}35.30 \\
(35.29) \\
\end{array}$ & 400 & 608 & 503 & 1.2 & 109 & $-\left[\mathrm{Cl}+75 \%\right.$ of $\left.\mathrm{bb}^{\mathrm{a}}\right]$ \\
\hline & \multicolumn{8}{|c|}{ Final residue $\left(2 \mathrm{Ni}+25 \%\right.$ of $\left.\mathrm{bb}^{\mathrm{a}}\right): 27.90 \%(28.04 \%)$} \\
\hline \multirow{5}{*}{  } & 1 & $\begin{array}{c}7.80 \\
(7.90) \\
\end{array}$ & 32 & 182 & 72 & 5 & 94 & $-2.5 \mathrm{H}_{2} \mathrm{O}$ \\
\hline & 2 & $\begin{array}{c}24.60 \\
(24.80) \\
\end{array}$ & 182 & 360 & 256 & 2.6 & 103 & $-4 \mathrm{Cl}$ \\
\hline & 3 & $\begin{array}{c}11.50 \\
(11.70) \\
\end{array}$ & 360 & 538 & 399 & 2.7 & 132 & $-\left[26 \%\right.$ of $\left.b b^{a}\right]$ \\
\hline & 4 & $\begin{array}{c}23.40 \\
(23.50) \\
\end{array}$ & 538 & 800 & 715 & 0.8 & 98 & $-\left[52 \%\right.$ of $\left.b^{a}\right]$ \\
\hline & \multicolumn{8}{|c|}{ Final residue $\left(2 \mathrm{Cu}+22 \%\right.$ of $\left.\mathrm{bb}^{\mathrm{a}}\right): 32.70 \%(32.10 \%)$} \\
\hline
\end{tabular}

\footnotetext{
${ }^{\mathrm{a}} \mathrm{bb}$; Backbone components
}

$\left(\mathrm{T}_{\mathrm{f}}\right)$ and maximum rate $\left(\mathrm{T}_{D T G}\right)$ temperatures of mass loss are given in Tables 4 and 5. The ligands BAT2 and BAT3 start losing $43 \%$ and $49 \%$ of their masses in two rapid and consecutive steps in the $130-414^{\circ} \mathrm{C}$ range, followed by slow and continuous bleeding of $41.5 \%$ and $29.8 \%$ mass losses in the $262-800^{\circ} \mathrm{C}$ range with $15.5 \%$ and $21.2 \%$ residual mass at the end of the reaction $\left(800^{\circ} \mathrm{C}\right)$, respectively. In the two apparent consecutivesteps, the strongly sharp peaks $\left(\mathrm{T}_{D T G}\right)$ at $249^{\circ} \mathrm{C}$ and $324^{\circ} \mathrm{C}$ due to the rapid and consecutive $19 \%$ and $24 \%$ mass losses with activation energies 234 $\mathrm{kJ} \mathrm{mol}^{-1}$ and $201 \mathrm{~kJ} \mathrm{~mol}^{-1}$ observed for the BAT2 ligand are more or less comparable with that at $230^{\circ} \mathrm{C}$ and $295^{\circ} \mathrm{C}$ with $19 \%$ and $30 \%$ mass losses and activation energies of $186 \mathrm{~kJ} \mathrm{~mol}^{-1}$ and 184 $\mathrm{kJ}$ mol$^{-1}$ observed for BAT3 ligand.

The TG/DTG curves of the metal-complexes in Figures 2 and 3 reveal that with overlapping steps being various, three, four or five steps in the sequential decomposition of BAT2 and BAT3 metal-complexes are observed. The 
Table 5. Characteristic parameters of thermal decomposition $\left(10^{\circ} \mathrm{C} \mathrm{min}^{-1}\right)$ for $\mathrm{Co}(\mathrm{II}), \mathrm{Ni}(\mathrm{II})$ and $\mathrm{Cu}$ (II) complexes of BAT3.

\begin{tabular}{|c|c|c|c|c|c|c|c|c|}
\hline \multirow[b]{2}{*}{ Comp. } & \multirow[b]{2}{*}{ Step } & \multicolumn{4}{|c|}{ TGA } & \multirow[b]{2}{*}{$\mathrm{n}$} & \multirow[b]{2}{*}{$\begin{array}{c}\mathrm{E}_{\mathrm{a}} / \\
\mathrm{kJ} \mathrm{mole}^{-1}\end{array}$} & \multirow[b]{2}{*}{ Reaction } \\
\hline & & $\begin{array}{l}\Delta \mathrm{m} \% \\
\text { found } \\
\text { (calc.) }\end{array}$ & $\mathrm{T}_{\mathrm{i}} /{ }^{\circ} \mathrm{C}$ & $\mathrm{T}_{\mathrm{f}} /{ }^{\circ} \mathrm{C}$ & $\mathrm{T}_{\mathrm{DTG}}$ & & & \\
\hline \multirow{3}{*}{ BAT3 } & 1 & 19 & 180 & 262 & 230 & 1.5 & 186 & - [19\% of Ligand] \\
\hline & 2 & 30 & 262 & 414 & 295 & 3.1 & 184 & - [30\% of Ligand] \\
\hline & \multicolumn{8}{|c|}{ Total mass loss $=78.8 \%$ and Final residue $=21.2 \%$; at $800^{\circ} \mathrm{C}$} \\
\hline \multirow{6}{*}{$\begin{array}{l}m \\
\stackrel{m}{0} \\
\dot{b} \\
\dot{j}\end{array}$} & 1 & $\begin{array}{c}14.60 \\
(14.80)\end{array}$ & 23 & 229 & 69 & 3.6 & 64 & $-\left[0.33 \mathrm{EtOH}+4.25 \mathrm{H}_{2} \mathrm{O}\right]$ \\
\hline & 2 & $\begin{array}{c}5.60 \\
(5.70)\end{array}$ & 229 & 315 & 286 & 1.4 & 167 & $-\mathrm{Cl}$ \\
\hline & 3 & $\begin{array}{c}11.50 \\
(11.40)\end{array}$ & 315 & 414 & 355 & 2.1 & 191 & $-2 \mathrm{Cl}$ \\
\hline & 4 & $\begin{array}{c}12.60 \\
(12.50) \\
\end{array}$ & 414 & 526 & 460 & 2 & 233 & $-\left[\mathrm{Cl}+15.5 \%\right.$ of $\left.\mathrm{bb}^{\mathrm{a}}\right]$ \\
\hline & 5 & $\begin{array}{c}29.40 \\
(29.50) \\
\end{array}$ & 526 & 800 & 662 & 1.4 & 141 & $-\left[67.5 \%\right.$ of $\left.b^{a}\right]$ \\
\hline & \multicolumn{8}{|c|}{ Final residue $\left(2 \mathrm{Co}+17 \%\right.$ of $\left.b^{\mathrm{a}}\right): 26.30 \%(26.10 \%)$} \\
\hline \multirow{6}{*}{$\begin{array}{l}\hat{\imath} \\
\stackrel{n}{1} \\
i \bar{z}\end{array}$} & 1 & $\begin{array}{c}15.70 \\
(15.80) \\
\end{array}$ & 34 & 275 & 66 & 3.7 & 58 & $-\left[0.2 \mathrm{EtOH}+5 \mathrm{H}_{2} \mathrm{O}\right]$ \\
\hline & 2 & $\begin{array}{c}5.57 \\
(5.62)\end{array}$ & 275 & 358 & 321 & 2.4 & 198 & $-\mathrm{Cl}$ \\
\hline & 3 & $\begin{array}{c}11.20 \\
(11.30) \\
\end{array}$ & 358 & 420 & 370 & 2.2 & 282 & $-2 \mathrm{Cl}$ \\
\hline & 4 & $\begin{array}{c}12.63 \\
(12.61) \\
\end{array}$ & 420 & 538 & 437 & 3.8 & 314 & $-\left[\mathrm{Cl}+16.2 \%\right.$ of $\left.\mathrm{bb}^{\mathrm{a}}\right]$ \\
\hline & 5 & $\begin{array}{c}25.60 \\
(25.50) \\
\end{array}$ & 538 & 796 & 669 & 3 & 170 & $-\left[59 \%\right.$ of $\left.b^{a}\right]$ \\
\hline & \multicolumn{8}{|c|}{ Final residue $\left.\left(2 \mathrm{Ni}+24.8 \% \text { of } b^{\mathrm{a}}\right)^{\mathrm{a}}\right): 29.30 \%(29.17 \%)$} \\
\hline \multirow{5}{*}{ 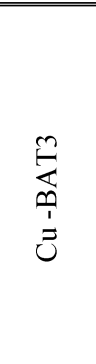 } & 1 & $\begin{array}{c}5.60 \\
(5.91) \\
\end{array}$ & 34 & 101 & 62 & 2 & 94 & $-\left[0.25 \mathrm{EtOH}+1.5 \mathrm{H}_{2} \mathrm{O}\right]$ \\
\hline & 2 & $\begin{array}{c}27.70 \\
(27.38) \\
\end{array}$ & 112 & 340 & 211 & 2 & 63 & $-\left[4 \mathrm{H}_{2} \mathrm{O}+3 \mathrm{Cl}\right]$ \\
\hline & 3 & $\begin{array}{c}13.70 \\
(13.79) \\
\end{array}$ & 340 & 500 & 377 & 3.4 & 149 & $-\left[\mathrm{Cl}+20 \%\right.$ of $\left.\mathrm{bb}^{\mathrm{a}}\right]$ \\
\hline & 4 & $\begin{array}{c}24.20 \\
(24.22) \\
\end{array}$ & 500 & 744 & 554 & 3.2 & 242 & $-\left[58 \%\right.$ of $\left.b^{a}\right]$ \\
\hline & Final & d 12 & $22 \%$ & $\left.b^{a}\right)$ & $80^{\circ}$ & 8.70 & & \\
\hline
\end{tabular}

${ }^{\mathrm{a}} \mathrm{bb}$; Backbone components

first decomposition steps of both ligands complexes between $23-275^{\circ} \mathrm{C}$ with mass losses ranging from 5.60 to $15.70 \%$ correspond to the coevolution of solvent with various number of adsorbed or/and coordinated water molecules (cal. 5.70-15.80\%), and as a result broad peaks either due to peaks overlapping or a gradual extending end $\left(\mathrm{T}_{\mathrm{f}}\right)$ is observed. The corresponding activation energy values of these steps range between 53 to $94 \mathrm{~kJ} \mathrm{~mol}^{-1}$.

The second-step of decomposition in the $112-400^{\circ} \mathrm{C}$ range indicates the mass losses between 5.57 and $27.70 \%$ may be due to either the release of various ratio of coordinated water molecules 

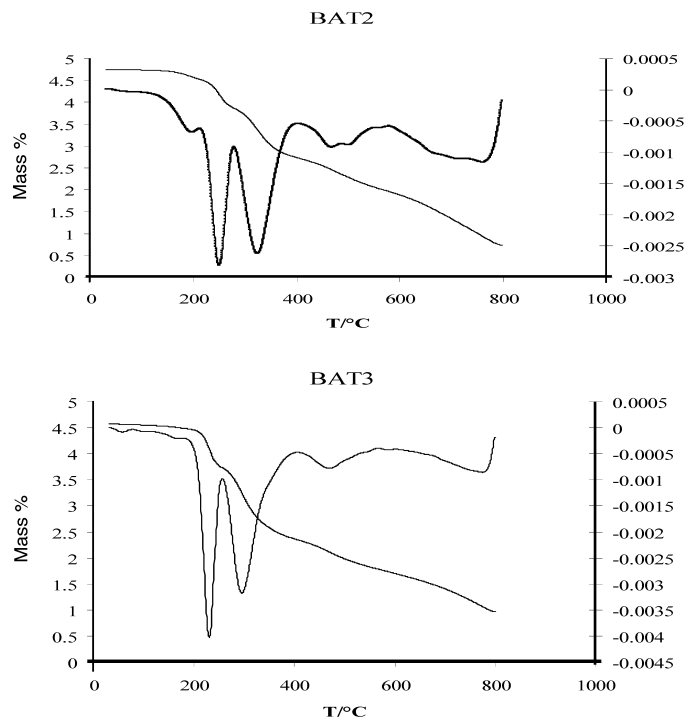

Figure 1. The TG and DTG thermograms of the BAT2 and BAT3 ligands in nitrogen at the heating

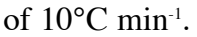

together with chloride atoms or various number of chloride atoms (cal. 5.62-27.38\%). These secondsteps show overlapping steps of either a very rapid or a gradual mass loss with activation energy falls in the $53-198 \mathrm{~kJ} \mathrm{~mol}^{-1}$ range.

The third-step of these complexes occurs at the $315-608^{\circ} \mathrm{C}$ range with a gradual mass loss ranging from 10.60 to $35.30 \%$. This corresponds to either the release of two chloride atoms, one chloride atom along with various percent of backbone components or various percent of backbone components (cal. 10.70 to $35.29 \%$ ) with activation energies between $109-282 \mathrm{~kJ} \mathrm{~mol}^{-1}$. The third-step $\left(400-608^{\circ} \mathrm{C}\right)$ is an end of reaction step for the decomposition of Ni-BAT2 complex leaving a $27.90 \%$ mass loss that is in consistent with the final product (cal. 28.04\%) of an ill-defined final state.

The fourth-step at the $414-648^{\circ} \mathrm{C}$ range is assigned to the removal of one chloride atom along with $15.5 \%$ of the backbone components (found $12.60 \%$, cal. $12.50 \%$ ), one chloride atom along with $16.2 \%$ of the backbone components (found $12.63 \%$, cal. $12.61 \%$ ) and $23 \%$ of the backbone components (found $10.80 \%$, cal. $10.70 \%$ ) in the decomposition process of Co-BAT3, Ni-BAT3 and Co-BAT2 complexes with activation energy of 233,314 and $237 \mathrm{~kJ} \mathrm{~mol}^{-1}$, respectively.


Figure 2. The TG and DTG thermograms of the Co, $\mathrm{Ni}$ and $\mathrm{Cu}$ complexes with BAT2 ligand in nitrogen at the heating of $10^{\circ} \mathrm{C} \mathrm{min}^{-1}$.

In the contrary, this fourth-step in the 499$800^{\circ} \mathrm{C}$ range is the end of decomposition of $\mathrm{Cu}-$ BAT2 and Cu-BAT3 complexes for eliminating the remaining $52 \%$ (found $23.40 \%$, cal. $23.50 \%$ ) and $58 \%$ (found $24.20 \%$, cal. $24.22 \%$ ) of the backbone components with the deposition of illdefined final residues $32.70 \%$ (cal. $32.10 \%$ ) and $28.80 \%$ (cal. $28.70 \%$ ) at the end of the reactions, respectively. Their activation energies found to 

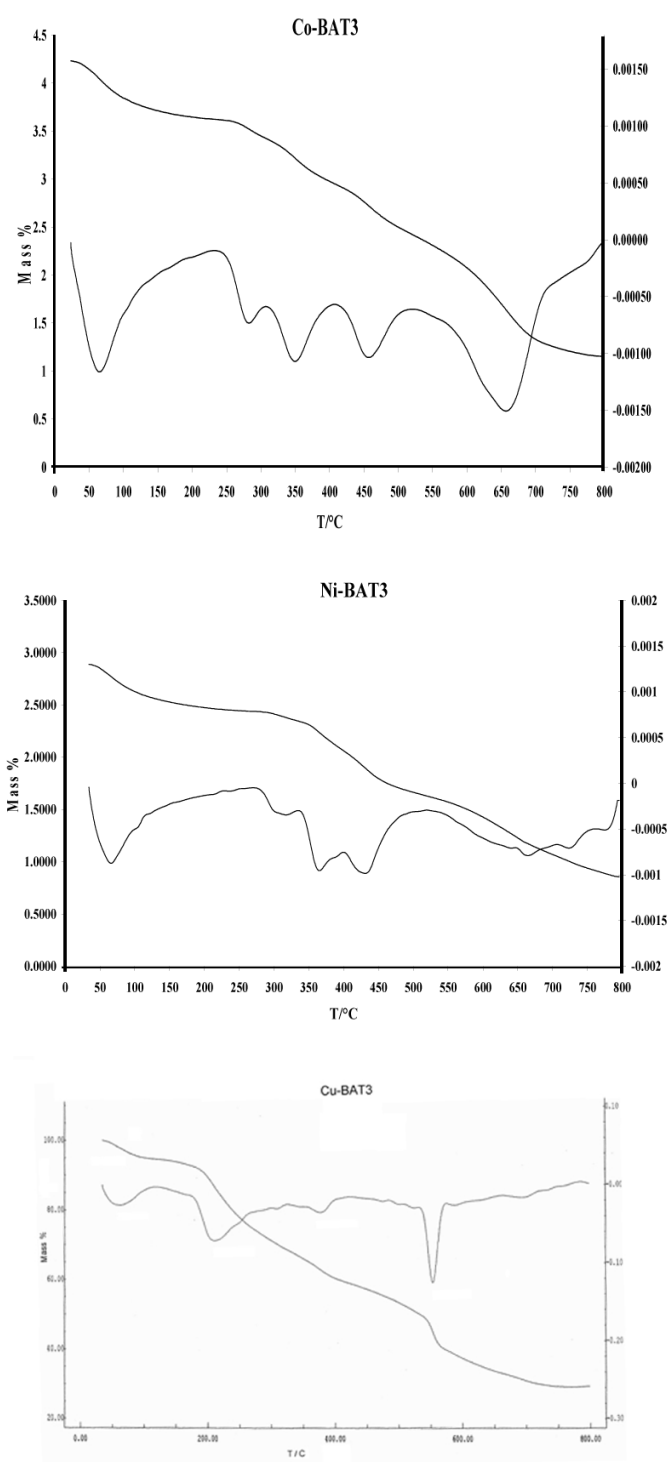

Figure 3. The TG and DTG thermograms of the Co, $\mathrm{Ni}$ and $\mathrm{Cu}$ complexes with BAT3 ligand in nitrogen at the heating of $10^{\circ} \mathrm{C} \mathrm{min}^{-1}$.

be 98 and $242 \mathrm{~kJ} \mathrm{~mol}^{-1}$, respectively. It is found that the release of the coordinated water molecules and chloride atoms fairly accord with literature [42, 43].

However, in the fifth-step of the 526$800^{\circ} \mathrm{C}$ range, the Co-BAT2, Co-BAT3 and $\mathrm{Ni}-$ BAT3 decompose completely by losing the remaining $28 \%$ (found $13.0 \%$, cal $13.0 \%$ ), $67.5 \%$ (found 29.40\%, cal 29.50\%) and 59\% (found $25.60 \%$, cal $25.50 \%$ ) of their backbone components with the deposition of ill-defined final products $33.20 \%$ (cal. 33.40\%), $26.30 \%$ (cal. $26.10 \%$ ) and $29.30 \%$ (cal. 29.17\%), and the associated activation energies are 316, 141 and 170 $\mathrm{kJ} \mathrm{mol}^{-1}$, respectively.

It can be concluded that the thermal decomposition of these six complexes is of a variety of degrees of similarity (Table 4 and 5). For instant, the first, second and third steps in the sequential decomposition of the square-planar complexes of Co-BAT2 and Cu-BAT2 are of very close thermal and kinetic parameters. This is, maybe, due to similar nature of decomposition process, i.e. similar mechanism and kinetics of the decomposition reaction that took place in the first three steps of the Co-BAT2 and Cu-BAT2 complexes. Acceptable similarities in the thermal and kinetic parameters are observed for the five steps in the decomposition sequence of the CoBAT3 and Ni-BAT3 octahedral complexes. However, this is inconsistent with the thermal decomposition of the octahedral complexes of $\mathrm{Ni}-\mathrm{BAT} 2$ and $\mathrm{Cu}-\mathrm{BAT} 3$ with their three and four steps in the decomposition process.

Biological activity

The ligands BAT1, BAT2, BAT3 and BAT4 under investigation and their $\mathrm{Co}$ (II) $\mathrm{Ni}$ (II) and $\mathrm{Cu}$ (II) complexes were screened in vitro for their antibacterial activity against four strains of bacteria, i.e. two gram-positive bacteria (Staphylococcus aureus, Streptococcus pyogenes) and two gram-negative bacteria (Haemophilus influenzae, Pseudomonas aeruginosa), and two fungal species (Aspergillus flavus and Candida albicans). Discs saturated with DMSO solvent, which show no zone of inhibition (-) were used as control and the results of the antibacterial and antifungal activities were summarized in Table 6.

The ligands BAT1, BAT2, BAT3 and BAT4 and their $\mathrm{Co}(\mathrm{II}), \mathrm{Ni}(\mathrm{II})$ and $\mathrm{Cu}$ (II) complexes are found to possess various antibacterial and antifungal activities towards the strains of the bacteria and the fungal species used. However, no inhibition zone is observed for the ligands BAT3 and BAT4 against the gram-posi- 
Table 6. Effect of the ligands and their $\mathrm{Co}(\mathrm{II}), \mathrm{Ni}(\mathrm{II})$ and $\mathrm{Cu}(\mathrm{II})$ Complexes on the growth of Bacteria and Fungi (Zone of inhibition in $\mathrm{mm}$ ).

\begin{tabular}{|c|c|c|c|c|c|c|}
\hline \multirow{3}{*}{$\begin{array}{l}\text { Compound } \\
(1000 \mu \mathrm{g} / \mathrm{ml})\end{array}$} & \multicolumn{4}{|c|}{ Bacteria } & \multicolumn{2}{|c|}{ Fungi } \\
\hline & \multicolumn{2}{|c|}{ gram-positive } & \multicolumn{2}{|c|}{ gram-negative } & $\begin{array}{l}\text { Aspergillus } \\
\text { flavus }\end{array}$ & $\begin{array}{l}\text { Candida } \\
\text { albicans }\end{array}$ \\
\hline & 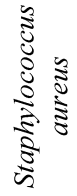 & 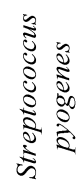 & 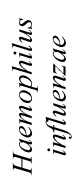 & 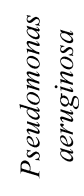 & & \\
\hline BAT1 & + & + & + & + & + & + \\
\hline BAT2 & +++ & ++ & + & + & ++ & + \\
\hline BAT3 & - & - & ++ & + & ++ & ++ \\
\hline BAT4 & - & - & + & + & + & + \\
\hline Co-BAT1 & ++ & + & + & + & + & + \\
\hline Co-BAT2 & ++ & +++ & + & + & + & + \\
\hline Co-BAT3 & + & ++ & + & + & + & + \\
\hline Co-BAT4 & + & + & + & + & + & + \\
\hline Ni -BAT1 & ++ & + & + & + & + & + \\
\hline Ni -BAT2 & ++ & +++ & + & + & ++ & ++ \\
\hline $\mathrm{Ni}-\mathrm{BAT} 3$ & ++ & + & + & + & + & + \\
\hline $\mathrm{Ni}-\mathrm{BAT} 4$ & + & + & + & + & + & + \\
\hline $\mathrm{Cu}$-BAT1 & ++ & + & + & + & + & + \\
\hline $\mathrm{Cu}-\mathrm{BAT} 2$ & ++ & ++ & ++ & + & ++ & + \\
\hline $\mathrm{Cu}-\mathrm{BAT} 3$ & ++ & - & + & ++ & + & + \\
\hline $\mathrm{Cu}-\mathrm{BAT} 4$ & + & + & + & + & + & + \\
\hline Ampicillin $25 \mu \mathrm{g} / \mathrm{ml}$ & + & + & + & + & & \\
\hline Mycostatin $30 \mu \mathrm{g} / \mathrm{ml}$ & & & & & +++ & +++ \\
\hline
\end{tabular}

$(-)$ No zones of inhibition were observed.

Moderately sensitive $(+)$, Inhibition zones of 7-10 mm.

Sensitive (++), Inhibition zones of 11-14 mm.

Highly sensitive (+++), Inhibition zones of 15-20 mm 
tive bacteria and only for the complex Cu-BAT3 against Streptococcus pyogene. The highest activity observed is for the BAT2 against Staphylococcus aureus and for the $\mathrm{Co}(\mathrm{II})$ and $\mathrm{Ni}$ (II) complexes of BAT2 towards Streptococcus pyogene. Apart from the above-mentioned ligands and complexes, the remaining ligands and metal complexes exhibit moderate to high antibacterial activity.

Apart from the ligands and metal complexes that possess a high activity against Aspergillus flavus and Candida albicans, all the rest of the ligands and the complexes exhibit moderate antifungal activities against the fungi tested.

It has been reported [16-18] that complexes of some heterocyclic ligands with transition metals increase their biological activities. This can be seen relatively more in the higher activity of the metals complexes towards Staphylococcus aureus than the free ligands, but slightly less against Streptococcus pyogene. In contrast, increasing the number of methylene groups between two heterocyclic rings may decrease the antibacterial activity of these compounds [19]. Close examination of the antibacterial activity of the ligands and their metal complexes reveals that the ligand BAT4 with the highest methylene groups and its metal complexes possess the lowest antibacterial activity against gram-positive bacteria than the others.

\section{Conclusion}

Based on the analytical data and the TGA results, the formulae and the stoichiometry of the prepared BATs ligands and their $\mathrm{Co}$ ( II) , Ni(II) and $\mathrm{Cu}$ (II) metal complexes are suggested. The IR spectral studies indicate neutral tetradentate behavior of the ligands coordinating through the amine group nitrogen and thione form sulphur. The molar conductance values show the nonelectrolytic nature of the complexes. The spectral and magnetic results reveal an octahedral geometry (structure I) for some of the complexes and a square-planer (structure II) for the others.

Generally, the metal-complexes of a particular ligand with various metals exhibit various thermal decomposition behavior, and the kinetic parameters for the successive steps in the decomposition sequence are determined. The inconsistent biological activities observed again the four strains of bacteria and the two fungal species reflect various degrees effect nature of these metal-complexes.

\section{Received May 152008 \\ Accepted August 262008}

\section{References}

[1] D.-K. Kim, J. Kim, and H.-J. Park, Bioorganic \& Medicinal Chemistry Letters. 14(10) (2004) 2401.

[2] B. Modzelewska-Banachiewicz, J. Banachiewicz, A. Chodkowska, E. Jagiello-Wojtowicz, and L. Mazur, European Journal of Medicinal Chemistry. 39(10) (2004) 873

[3] L. Tian, Y. Sun, H. Li, et al, Journal of Inorganic Biochemistry. 99(8) (2005) 1646.

[4] J. Liu, L. Li, H. Dai, Z. Liu, and J. Fang, Journal of Organometallic Chemistry. 691(12) (2006) 2686.

[5] M. Serdar, N. Gumrukcuoglu, S. Alpay Karaoglu and N. Demirbas, Turk J Chem. 31 (2007) 315.

[6] N. Demirbas, A. Demirbas, S. A. Karaoglu and E. Celik, ARKIVOC. I (2005) 75.

[7] P. F. Xu, X. W. Sun, L. M. .Zhang and Z. Y. Zhang, J. Chem. Research (S). (1999) 170.

[8] Z. Y. Zhang, X. Chen, L. L. Wei and Z. L. Ma, Chemical Research in Chinese Universities. 2 (1991) 129.

[9] X. Zhu, Y. M. Zhang, B. L. Li and Y. Zhang, Journal of Coordination Chemistry. 59(5) (2006) 513.

[10] P. Thakur, V. Chakravortty and K. C. Dash, Polyhedron. 16(9) (1997) 1417.

[11] K. C. Rout, R. R. Mohanty, S. Jena and K. C. Dash, Polyhedron. 15(56) (1996) 1023.

[12] J. A. Joule, K. Nills, G. F. Smith, Heterocyclic Chemistry, Chapman and Hall, London, 3rd edn., 1995.

[13] K.B. Gudasi, P. B. Maravalli and T. R. Goudar, J. Serb. Chem. Soc. 70(4) (2005) 643.

[14] T. A. Khan and Shahjahan, Synthesis and Reactivity in Inorganic, Metal-Organic, and Nano-Metal Chemistry. 31(6) (2001) 1023.

[15] A. W. Coats and J. P. Redfern, "Kinetic parameters from thermogravimetric" Nature. 201 (1964) 68.

[16] A. E. Liberta and D. X. West, BioMetal, 5(2) (1992) 121. [17] E. Rodriguez-Fernandez, J. L. Manzano, J. J. Benito, R. Hermosa, E. .Monte, J..J. Criado, Journal of Inorganic Biochemistry, 99(8) (2005) 1558.

[18] G. K. Zahariou, E. Gavrielatos, I. M. Kalogeras, G. Athanasellis, A. Vassilikou-Dova, O. Igglessi-Markopoulou, J. Markopoulos, Radiation Effects and Defects in Solids. 157(6-12) (2002) 1057.

[19] K. Zamani, K. Faghihi, M.S, Mehranjani, Pol. J. Pharmacol. 55 (2003) 1111.

[20] A.I. Vogel “A Text Book of Quantitative Inorganic Analysis" Longmans, London ,1961.

[21] A. M. Sh El-Sharief, Y. A. Ammar, M. A. Zahran, A. H. Ali and M. S. A. El-Gaby, Afindad. 60(503) (2003) 32.

[22] Z. Szafran, R. M. Pike and M. M. Singh, "Microscale Inorganic Chemistry” John Wiley,lNC, New York , 1991. 
[23] R. R. Amin, A. T. Al-Subaie, B A. El-Gamal, A.M Mahasneh and I.S. Al-Naimi, Journal of the Medica Research Institute. 22(1) (2001) 1.

[24] A. A. El-Asmy, M. E. Khalifa, and M. M. Hassanian, Synth. React. Inorg. Met.-Org. Chem., 31(10) (2001) 1787.

[25] M. Arshad, Saeed-ur-Rehman, S. A. Khan, K. Masud, N. Arshad and Abdul Ghni, Thermochimica Acta. 364 (2000) 143.

[26] K. S. Siddiqi, R. I. Kureshy, N. H. Hkan, S. Tabassum And S. A. A. Zaidi, Inorganic Chimica Acta. 151(2) (1988) 95.

[27] N. M. El-Metwally, I. M. Gabr, A. A. El-Asmy, A.A Abou-Hussen, Transition Metal Chemistry. 31 (2006) 71.

[28] A. A. El-Asmy, M. A. Morsi and A. A. El-Shafei, Transition Met. Chem. 11 (1986) 494.

[29] Y. Zhang, W. Ruan, X. Zhao, H. Wang and Z. Zhu, Polyhedron. 22(12) (2003) 1535.

[30] N. M. El-Metwally, A. A. El-Asmy, A.A. Abou-Hussen, International Journal of Pure \& Applied Chemistry. 1(1) (2006) 75.

[31] A. A. El-Asmy, M. E Khalifa, T. H. Rakha, M. M. Hassanian, A. M. Abdallah, Chem. Pharm. Bull.,48 (2000) 41.

[32] A. B. P. Lever, "Inorganic Electronic Spectroscopyî, Elsevier, Amsterdam, 1968.
[33] A. A. El-Asmy, Synth. react. Inorg. Met.-Org. Chem.. 17 (1987) 399.

[34] N. C. Saha, R. J. Butcher, S. Chaudhuri and N. Saha, Polyhedron. 22(3) (2003) 383.

[35] A. A. El-Asmy, T.Y. Al-Ansi, M..Mounir and S. A. Ashour, Synth. React. Inorg. Met.-Org. Chem. 19(4) (1989) 309.

[36] G. G. Mohamed, M. .M. Omar, A. M. M. Hindy, Spectrochimica Acta. (A 62) (2005) 1140.

[37] A. A. El-Asmy, Ph D thesis. Faculty of Science, Mansoura University, Egypt, 1981.

[38] N. M. El-Metwally, I. M. Gabr, A. M. Shallaby And A. A. El-Asmy, Journal of Coordination Chemistry. 58(13) (2005) 1145.

[39] G. A. A. Al-Hazmi, M. S. El-Shahawi, I. M. Gabr And A. A. El-Asmy, Journal of Coordination Chemistry. 58(8) (2005) 713.

[40] F.A. El-Saied, M.I. Ayad, R.M. Issa and S.A. Aly, , Polish J. Chem., Inorganic Chemistry. 75 (2001) 773.

[41] A. A. El-Asmy, T. Y. Al-Ansi, R. R. Amin, M. F. El Shahat, Trans. Metal Chem. 15 (1990) 12.

[42] H. Al-Maydama, A. El-shekeil M. A. Khalid and A. AlKarbouly, Ecl. Quim., Sao Paulo. 31(1) (2006) 45.

[43] P. B. Maravalli and T. R Goudar, Thermochimica Acta. 325 (1999) 35 